Выполнение норм, отраженных в правилах дорожного движения, необходимо всем людям всегда и везде. Поэтому главным результатом работы с обучающимися должен являться не только комплекс теоретических знаний, но и сформированный у всех школьников высокий уровень культуры безопасного поведения на дорогах, который характеризуется системой знаний, умений и навыков безопасного участия в дорожном движении [2].

1. Воронова, Е.А. Красный. Желтый. Зеленый! ПДД во внеклассной работе / Е.А. Воронова. - Ростов н/Д: Феникс, 2008. - 251 с.

2. Данченко, С.П. Профилактика детского дорожно-транспортного травматизма: план СанктПетербурга / С.П. Данченко, М.Л. Форштат // ОБЖ. Основы безопасности жизни. - М.: Русский журнал, 2009.-№ 1. - С.54-57.

3. Форштат, М. Новая концепция БдД / М. Форштат // ОБЖ. Основы безопасности жизни. - М.: Русский журнал, 2004. - № 12. - С. $43-47$.

4. Форштат, М. Дети на дорогах / М. Форштат // ОБЖ. Основы безопасности жизни. - М.: Русский журнал, 2004. - № 6. - С. $43-44$.

\title{
Проданова О.С. \\ Организации учебного процесса по формированию социокультурной компетенции на занятиях по английскому языку
}

Университетский колледж ОГУ

(Россия, Оренбург)

doi: $10.18411 / \mathrm{j}-05-2021-247$

\section{Аннотация}

В данной статье рассматриваются вопросы формирования социокультурной компетенции на уроках иностранного языка, как неотъемлемой части коммуникативной компетенции. По мнению автора обучение иностранным языкам имеет четко выраженную культуроведческую направленность. Затрагиваются вопросы выбора способов и видов межкультурного взаимодействия на уроках английского языка. Особое внимание уделяется выбору тематики общения при формировании социокультурной компетенции. Далее автор описывает различные методы и приемы реализации в образовательном процессе социокультурного подхода к преподаванию иностранных языков.

Ключевые слова: социокультурная компетенция, коммуникативная компетенция, диалог культур, технологии обучения, проектная методика.

\section{Abstract}

This article deals with the formation of socio-cultural competence in the foreign language teaching, as an integral part of the communicative competence. According to the author, teaching foreign languages has a clearly expressed cultural orientation. The article deals with the choice of ways and types of intercultural education in English lessons. Special attention is paid to the choice of communication topics in the formation of socio-cultural competence. Further, the author Next, the author describes various methods and techniques for implementing a socio-cultural approach to teaching foreign languages in the educational process.

Key words: socio-cultural competence, communicative competence, dialogue of cultures, learning technologies, project-based methodology.

В связи с развитием международных связей возникает тенденция к возрастанию роли иностранного языка в жизни человека. Начали интенсивно развиваться прямые международные связи в различных сферах деятельности. Наше общество стало более 
мобильным: зарубежный туризм, учеба и трудоустройство за границей, расширение культурных связей - становятся реальностью и требует хорошего владения иностранными языками.

На всех этапах обучения иностранному языку в качестве основной цели выдвигают формирование коммуникативной компетенции, составной частью которой является социокультурная компетенция, которая включает в себя знание культурных особенностей носителей изучаемого языка, их традиций и привычек, норм поведения, а также умение понимать и адекватно использовать эти знания в процессе общения, оставаясь при этом носителем собственной национальной культуры.

В настоящее время обучение иностранным языкам имеет четко выраженную культуроведческую направленность, изучаемый иностранный язык становится не только средством коммуникации, но и инструментом приобщения к мировой культуре. Помимо выполнения коммуникативной функции обучение любому языку предполагает глубокое проникновение в культуру его носителей. Изучая иностранный язык, изучают не только лингвистические единицы разных уровней, но также знакомятся с культурой, ментальностью, особенностями повседневного образа жизни народа изучаемого языка. Поэтому так важно привлекать в учебно-воспитательный процесс материалы культуроведческой направленности, так как этот материал способствует повышению мотивации учения. Культурологический подход при обучении иностранному языку рассматривается как процесс двусторонний, а именно как диалог культур.

Диалог культур - это процесс взаимодействия различных культур, в результате которого каждая культура не только познает другую, но и осознает себя. Познавая чужую культуру, обучающиеся глубже постигают свою собственную. Ведь изучение культуры какой-то определённой страны не может происходить без опоры на отечественную национальную культуру и без учета местных (региональных) реалий конкретной социокультурной сферы - знания истории своего народа, существующих традиций, обрядов, - всего того, что входит в понятие национальной культуры. Безусловно, самым эффективным средством развития социокультурной компетенции является погружение в саму атмосферу культуры, пребывание в стране изучаемого языка, непосредственное знакомство с традициями, обычаями и социальными нормами страны изучаемого языка. Однако это доступно далеко не всем, поэтому необходим поиск эффективных путей развития социокультурной компетенции вне языковой среды.

В контексте диалога культур преподавание иностранного языка требует применения особых технологий обучения, отбора наиболее эффективных методов и приёмов. В настоящее время перед преподавателями иностранного языка ставятся новые задачи и открываются новые возможности. Обучение языку больше не ограничивается ни временем, ни местом. В повседневной и профессиональной жизни современного специалиста телекоммуникация и информационные технологии играют огромную роль, поэтому развитие межкультурной компетенции невозможно без разработки новых концепций и ресурсов использования информационных и коммуникационных технологий.

Какие же средства будут максимально эффективны для развития социокультурной компетенции у изучающего иностранный язык вне языковой среды? Необходимо учитывать все возможности, которыми обладают учебная группа, школа, регион для создания условий формирования межкультурной коммуникации как внутри страны, так и за ее пределами (рис.2). При этом все возможные виды межкультурного взаимодействия призваны стать неотъемлемым компонентом образовательного процесса. 

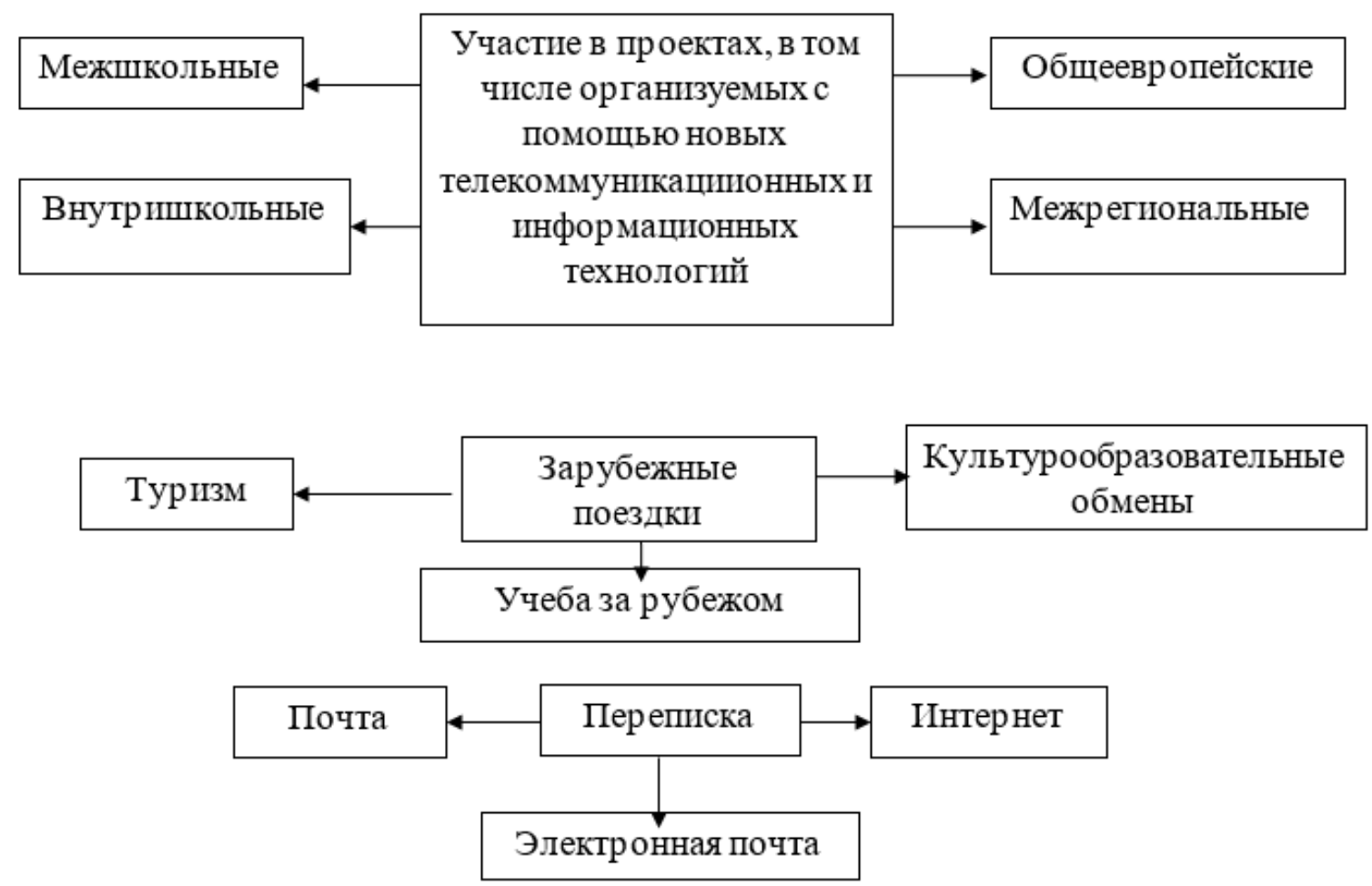

Рис.2. Способы и виды межкультурного взаимодействия

Тематика общения играет огромную роль при формировании социо-культурной компетенции на уроках иностранного языка. Обучающийся является активным участником общения, что и предполагает коммуникативная направленность обучения иностранным языкам. Но, так как общение является личностным процессом, коммуникация становится возможной при условии, что собеседникам интересно общаться друг с другом. Проблемы, к которым не тянется «мостик» из собственной реальности, из собственного культурного опыта, никогда не заинтересуют обучающихся. Поэтому при выборе тематики общения на уроке иностранного языка лучше всего выбирать общепризнанные темы как: рождение, жизнь, семья, отношение в производственной сфере, дружба, любовь, дом, жилище, природа, работа, воспитание подрастающего поколения, поездки, путешествия, свободное время и т.д. При выборе материала с точки зрения его культурологической и социокультурной направленности, следует обращать внимание на такой материал, который будет воспитывать у обучающихся уважение к культуре другого народа, пробуждать желание узнать как можно больше о стране изучаемого языка, будет способствовать стремлению к миру, сотрудничеству, сближению народов, проявлению толерантности.

Несмотря на различные способы и виды межкультурного взаимодействия знакомство с жизнью стран изучаемого языка происходит в основном через текст и иллюстрации к нему. Поэтому для формирования социокультурной компетенции на уроках иностранного языка большое значение имеет использование аутентичных материалов. Значительное место среди текстов занимают такие их виды, как письма, рекламные объявления, вывески, анкеты, меню и др. Весь материал, содержащий социокультурную направленность, отбирается с учетом возрастных особенностей обучаемых и их интересов. Овладение этим материалом позволит изучающим иностранный язык лучше ориентироваться в стране изучаемого языка в случае ее реального посещения. Наряду с этим важно дать обучающимся наглядное представление о жизни, традициях, языковых реалиях стран изучаемого языка. Этой цели также могут служить учебные видеофильмы. Использование аутентичных текстов и видеозаписей на уроках способствует индивидуализации обучения и 
развитию мотивированности речевой деятельности обучаемых. Использование различных каналов поступления информации (слуховой, зрительный, моторное восприятие) положительно влияет на прочность усвоения страноведческого и языкового материала.

Преподавание иностранного языка в контексте диалога культур требует разработки особой технологии обучения, отбора наиболее эффективных методов и приёмов. Задача учителя-практика решать эту проблему самостоятельно и творчески.

Одним из путей реализации идеи развития и воспитания в контексте «диалога культур» считаю проектную методику в обучении иностранному языку. Выполнение заданий проекта выходят за рамки урока и требуют много времени, но часто усилия оправдывают себя, так как при этом решается ряд важных задач:

- занятия не ограничиваются приобретением обучающимися определённых знаний, умений и навыков, а выходят на практические действия обучающихся, затрагивая их эмоциональную сферу, благодаря чему усиливается мотивация при изучении иностранного языка;

- обучающиеся получают возможность осуществлять творческую работу в рамках заданной темы, самостоятельно добывая необходимую информацию не только из учебников, но и из других источников;

— в проекте успешно реализуются различные формы организации учебной деятельности, в ходе которых осуществляется взаимодействие обучающихся друг с другом и учителем, роль которого меняется: вместо контролёра он становится равноправным партнёром и консультантом;

— в проектной работе весь учебный процесс ориентирован на обучающегося: здесь, прежде всего, учитываются его интересы, жизненный опыт и индивидуальные способности;

- усиливается индивидуальная и коллективная ответственность обучающихся за конкретную работу в рамках проекта, так как каждый обучающийся, работая индивидуально или в микрогруппе, должен представить всей группе результаты своей деятельности и это в свою очередь способствует воспитанию у подростков нравственности;

- в рамках подготовки к проекту обучающиеся полностью проникаются его идеей и эта идея несёт в себе большой воспитательный потенциал.

Работа с проектом имеет следующие этапы:

I. Подготовительный, который включает в себя следующие шаги:

1. Планирование учителем проекта в рамках тем программы.

2. Выдвижение идеи учителем на уроке.

3. Обсуждение идеи обучающимися; выдвижение ими своих идей; аргументирование своего мнения (этот этап имеет место, если речь идёт о большом, т. е. длительном проекте).

II. Организация работы:

1. Формирование микрогрупп.

2. Распределение заданий в микрогруппах.

3. Практическая деятельность обучающихся в рамках проекта.

III. Завершающий этап:

1. Промежуточный контроль (при длительном проекте).

2. Обсуждение способа оформления проекта.

3. Документирование проекта.

4. Презентация результатов проекта всей группе

5. Подведение итогов выполнения проектов: обсуждение результатов, выставление оценок и т.д. 
IV. Этап практического использования результатов проекта (в качестве наглядных пособий, выставки и т.д.).

В заключение хочу сделать вывод, что изучение культурного пространства, которое моделируется с помощью современной учебной литературы по иностранным языкам, практика культуроведческого наполнения занятий по иностранным языкам, методические приёмы работы учителя на уроке подразумевают овладение социокультурными знаниями и умениями, что обеспечивает реализацию воспитательных, общеобразовательных и практических целей обучения иностранным языкам. При обучении иностранным языкам в контексте диалога культур возникают неограниченные воспитательные возможности, если иностранный язык используется как средство приобщения учащихся к духовной культуре других народов и познания действительности путем иноязычного общения, как способ самопознания и самовыражения личности в процессе общения. Изучение аутентичных текстов, чтение газет и журналов на иностранным языке, прослушивание аудиокассет, просмотр видеофильмов знакомит обучаемых с культурой другого народа, помогает выявить сходство и различия в культуре двух народов, дает обучающимся возможность подругому взглянуть на проблемы своих сверстников в стране изучаемого языка, познакомиться со спецификой менталитета народа, нравами, обычаями, стилем жизни страны изучаемого языка. В организации своей работы (урок, внеурочная и внеклассная деятельность) я исхожу из позиции: помочь обучающемуся осознать уникальность собственной личности и развить способность адекватно оценивать свои реакции, детально и вдумчиво подходить к рассмотрению явления, научиться строить отношения с людьми, с представителями иных культур.

$$
* * *
$$

1. Баранова Н.В., Гусева С.Б. Социокультурные компоненты в содержании обучения немецкому языку/ Н.В. Баранова.- // Иностранные языки в школе. - 2001. - № 4. - С. $42-45$.

2. Бим И.Л. Некоторые актуальные проблемы современного обучения иностранным языкам // Иностранные языки в школе. - 2001. - №4. - С. 5-8.

3. Гальскова Н.Д. Межкультурное обучение: проблема целей и содержания обучения иностранным языкам // Иностранные языки в школе. - 2004. - №1. - С. 3-8.

4. Сафонова В.В. Изучение международного общения в контексте диалога культур и цивилизаций. Воронеж: ИСТОКИ, 1996.

5. Сафонова В.В. Социокультурный подход: основные социально-педагогические и методические положения//Иностранные языки в школе. - №11. - М: Просвещение, 2014 г. - с.2-13.

\section{Прохорова И.К.}

\section{Педагогическая практика студентов как условие становления будущего учителя}

Нижнетагильский государственный социально-педагогический институт (филиал) ФГАОУ ВО «Российский государственный профессионально-педагогический

doi: $10.18411 / l j-05-2021-248$

(Россия, Нижний Тагил)

\section{Аннотация}

В статье рассматривается проблема подготовки студентов педагогического вуза к будущей профессиональной деятельности в условиях педагогической практики. Представлены результаты исследования, проведенного со студентами четвертого курса педагогического вуза.

Ключевые слова: педагогическая практика студентов, система подготовки будущего учителя. 